\title{
Unilateral Intrauterine Horn Insemination of Frozen Semen in Cats
}

\author{
Toshihiko TSUTSUI ${ }^{1)}$, Akihiro TANAKA ${ }^{1)}$, Yuuko TAKAGI ${ }^{1)}$, Kiyoshi NAKAGAWA ${ }^{1)}$, Youko FUJIMOTO ${ }^{1)}$, \\ Mayumi MURAI ${ }^{1)}$, Mizuho ANZAI ${ }^{1)}$ and Tatsuya HORI ${ }^{1)}$ \\ ${ }^{1}$ Department of Reproduction, Nippon Veterinary and Animal Science University, 7-1 Kyonan-cho 1 chome, Musashino-shi, Tokyo 180- \\ 8602, Japan
}

(Received 4 February 2000/Accepted 10 August 2000)

ABSTRACT. Frozen feline semen was prepared using two types of extenders, egg yolk Tris-fructose citric acid (EYT-FC) and egg yolk sodium citrate solution (EYC), and the semen qualities after thawing and the conception rates obtained by unilateral intrauterine horn insemination (UIUI) were investigated. Cats used in the experiment were six males and 11 females aged 2-12 years (the number of experimental cases was 17). For preparation of frozen semen, semen collected by the artificial vagina method was adjusted to $1 \times 10^{8}$ sperm $/ \mathrm{m} l$ and $7 \%$ glycerol, put in $250 \mu l$ straws, and then frozen using a cell freezer. The mean sperm motility after thawing was 30.0 \pm 9.7 (SE) \% in the semen prepared with EYT-FC and $30.0 \pm 3.3 \%$ in the semen prepared with EYC. Four of seven animals were fertilized by UIUI using two straws in both extenders, and the conception rate was $57.1 \%$. The mean ratios of number of kits to the number of ovulations in the inseminated side were $61.1 \pm 24.5 \%$ and $30.5 \pm 3.4 \%$ for EYT-FC and EYC, respectively, showing that the ratio tended to be higher in the semen prepared with EYT-FC. The above findings, comparing the two extenders for preparation of frozen feline semen, showed that EYT-FC is slightly superior to EYC. To increase conception and fertility rates, it may be important to increase the sperm count for insemination and to inseminate both uterine horns.

KEY WORDS: feline, frozen semen, intrauterine insemination, straw method.

J. Vet. Med. Sci. 62(12): 1247-1251, 2000

Feline artificial insemination (AI) using frozen semen has been reported only by Platz et al. in 1978 [3]. In their study, $50-100 \times 10^{6}$ viable sperms were inseminated into the vagina. Although only six of 56 animals were fertilized, obtaining a conception rate of $10.7 \%$, these were the first cases of fertilization by frozen semen in cats. We previously performed intravaginal insemination (IVI) of fresh semen and clarified that a number of sperms, $80 \times 10^{6}$, are required for fertilization [6]. This sperm count is equal to the number of sperm in two ejaculations in cats [5]. We also clarified the sperm count required for fertilization by unilateral intrauterine horn insemination (UIUI) of fresh semen to be $8 \times 10^{6}$ in cats, which is $1 / 10$ of that by IVI [7]. Freezing markedly reduces motility and viability of sperms. Accordingly, it is important to develop a technique of fertilizaiton using a small number of sperm. Therefore, intrauterine insemination (IUI) may be appropriate for feline AI using frozen semen rather than IVI.

The method using frozen feline semen reported by Platz et al. was the pellet method, which may pose difficulties for storage and use [3]. Therefore, we investigated freezing of feline semen by the straw method.

Platz et al. used egg yolk lactose as the extender for frozen feline semen [3]. However, the semen qualities after thawing were not reported, and thus, we could not evaluate the extender used in their study. Therefore, we prepared frozen feline semen using egg yolk fructose citric acid (EYT-FC) $[6,7]$, which we use as an extender for fresh feline semen, and egg yolk sodium citrate (EYC), which is an extender of bovine semen [4], and compared the semen quality after thawing and the conception rate obtained by UIUI. To ensure uniform conditions for the freezing method, a cell freezer (Cell Freezer R204, England) was used. For AI, UIUI was performed, as reported [7] for insemination of fresh semen, and we investigated the fertilization of ova in the non-inseminated uterine horn by the inseminated sperms. Because a higher conception rate was previously obtained by insemination before ovulation than insemination after ovulation, AI was performed 15 or $20 \mathrm{hr}$ after hCG administration, a time point predicted to be prior to ovulation [7].

\section{MATERIALS AND METHODS}

Animals: Six males cats aged 2-12 years with normal semen qualities, copulation capability, and fertility, from which semen were collected by the artificial vagina (AV) method, were used for the experiment. For females subjected to AI, 11 female cats aged 2-7 years bred and maintained in our colony were repeatedly used, and the number of experimental cases was 17. All these female cats had experienced pregnancy and delivery 1-3 times. The animals were maintained in an animal room in which the temperature was kept at $23 \pm 2{ }^{\circ} \mathrm{C}$. Male cats were individually kept in cages measuring $60 \times 90 \times 120(\mathrm{~h}) \mathrm{cm}$, and female cats were kept in a group in a room measuring $4 \times 7 \mathrm{~m}$. The animals were supplied dry food (Hill's Feline Maintenance, U.S.A.) and drinking water ad libitum. Females were placed with males every day in the morning and evening to observe estrus.

Semen collection and examination of semen quality: Semen was collected using an AV for cats that was previously reported [5].

While a male cat mounted an estrous female cat and thrust, the penis was advanced into an AV held between the forefinger and middle finger, and ejaculation was induced. Using 
Table 1. Composition of extenders used for preparation of frozen semen in cats

\begin{tabular}{lcccccc}
\hline \multirow{2}{*}{ Ingredients } & \multicolumn{2}{c}{ EYC } & & \multicolumn{2}{c}{ EYT-FC } \\
\cline { 2 - 3 } \cline { 6 - 7 } \cline { 5 - 6 } & 1st extender & 2nd extender & & 1st extender & 2nd extender \\
\hline Sodium citrate dihydrate & $1.45 \mathrm{~g}$ & $1.21 \mathrm{~g}$ & & - & $\mathrm{g}$ & - \\
Citric acid & - & - & & $1.30 \mathrm{~g}$ & $1.30 \mathrm{~g}$ \\
Disodium hydrogenphosphate 12-water & $0.17 \mathrm{~g}$ & $0.14 \mathrm{~g}$ & & - & - & - \\
Tris (hydroxymethyl) aminomethane & - & & - & & $2.40 \mathrm{~g}$ & $2.40 \mathrm{~g}$ \\
Glucose & $1.70 \mathrm{~g}$ & $1.42 \mathrm{~g}$ & & - & - \\
Lactose & $0.26 \mathrm{~g}$ & $0.21 \mathrm{~g}$ & & - & - \\
Fructose & - & - & & $1.00 \mathrm{~g}$ & $1.00 \mathrm{~g}$ \\
Penicillin potassium & $100,00 \mathrm{U}$ & $100,000 \mathrm{U}$ & & $100,000 \mathrm{U}$ & $100,000 \mathrm{U}$ \\
Streptomycin sulfate & $0.10 \mathrm{~g}$ & $0.10 \mathrm{~g}$ & & $0.10 \mathrm{~g}$ & $0.10 \mathrm{~g}$ \\
Glycerol & - & $14 \mathrm{~m} l$ & & - & $14 \mathrm{~m} l$ \\
Egg yolk & $20 \mathrm{~m} l$ & $20 \mathrm{~m} l$ & & $20 \mathrm{~m} l$ & $20 \mathrm{~m} l$ \\
Distilled water to final volume & $100 \mathrm{~m} l$ & $100 \mathrm{~m} l$ & & $100 \mathrm{~m} l$ & $100 \mathrm{~m} l$ \\
\hline
\end{tabular}

the same AV, a second semen collection was performed. To avoid drying, $100 \mu l$ of the extender (primary extender) was added to the semen, and a previously determined general test for semen quality was performed as we previously reported [5]. Frozen semen was prepared using semen with a sperm motility of $80 \%$ or greater.

Frozen semen: Two types of extenders, EYT-FC and EYC shown in Table 1, were used as the extender of frozen semen. After the semen quality test, semen was subjected to the 1st dilution at $20^{\circ} \mathrm{C}$ to adjust the sperm count to $2 \times 10^{8} / \mathrm{ml}$, and was then kept in a water bath at $4^{\circ} \mathrm{C}$ for one hour for the $1 \mathrm{st}$ cooling. After the 1 st cooling, using the secondary extender supplemented with $14 \%$ glycerol, the 2 nd dilution of the semen was performed by dripping at $4^{\circ} \mathrm{C}$, taking approximately 10 min with stirring using a stirrer. The semen was diluted with an equal volume of the extender, and thus, the final sperm concentration was $1 \times 10^{8} / \mathrm{m} l$, and the final glycerol concentration was $7 \%$. After the 2 nd dilution, the semen was put in $250 \mu l$ straws, and equilibrated with glycerol for one hour. Then, the semen was frozen using Cell Freezer $\mathrm{R} 204$. The temperature conditions for freezing were $-1.0^{\circ} \mathrm{C} /$ $\min$ from $4^{\circ} \mathrm{C}$ to $-1.0^{\circ} \mathrm{C},-33.0^{\circ} \mathrm{C} / \mathrm{min}$ from $-1.0^{\circ} \mathrm{C}$ to $-50^{\circ} \mathrm{C}$, and $-58.4^{\circ} \mathrm{C} / \mathrm{min}$ from $-50^{\circ} \mathrm{C}$ to $-196^{\circ} \mathrm{C}$. When the temperature reached the maximal cooling temperature, $-196^{\circ} \mathrm{C}$, the semen was transferred to a liquid nitrogen container.

Examination of semen qualities after thawing: The feline semen qualities after thawing were compared at each dilution among four cases. The semen preparations frozen for one week or more were thawed in a water bath at $37^{\circ} \mathrm{C}$ for $30 \mathrm{sec}$, and the qualities were examined. In the semen quality test, the motility, viability, and abnormality of the sperm were evaluated.

Ovulation induction method: Ovulation was induced by administration of $100 \mathrm{iu} \times 2 \mathrm{hCG}$ into the jugular vein on days 2-4 of estrus. Cats that were before ovulation at insemination received a second administration immediately after surgery. To evaluate the success of induction of ovulation in the animals that were before ovulation at insemination excluding pregnant animals, when the peripheral blood progesterone $(\mathrm{P})$ level 15 days after hCG administration was increased, induction of ovulation was judged to have been successful. The P level was measured by EIA [2].

$A I$ : In UIUI of frozen feline semen prepared using two extenders, semen stored for 1-19 months was used. AI was performed 15 or $20 \mathrm{hr}$ after hCG administration.

UIUI was performed under general anesthesia. For anesthesia, after pretreatment with atropine sulfate $(0.05 \mathrm{mg} / \mathrm{kg})$ and acepromazine maleate $(0.025 \mathrm{mg} / \mathrm{kg})$, ketamine $(5 \mathrm{mg} /$ $\mathrm{kg}$ ) was administered for induction of anesthesia, then the anesthesia was maintained by halothane $[6,7]$.

The semen of two straws $\left(50 \times 10^{6}\right.$ sperms $)$ was inseminated. The semen was thawed, and after semen quality test, the semen was centrifuged at $230 \mathrm{G}$ for $5 \mathrm{~min}$, and approximately $30 \mu l$ after removing the supernatant was used. The animals were laparotomized along the median line, and semen was inseminated into the uterine horn with a higher number of mature ovarian follicles (or ovulation).

An 18G needle was inserted into the central region of the uterine horn, and semen was inseminated into the tip of the uterine horn using an injector consisting of a $20 \mathrm{G}$ indwelling needle connected to a $1 \mathrm{~m} l$ syringe. After insemination, the injury made by inserting the needle was one-stitched with a soluble suture. Follicles with a diameter of $4 \mathrm{~mm}$ or greater were regarded as mature follicles, and all these mature follicles were supposed to have been ovulated by hCG administration.

Diagnosis of pregnancy: As we previously reported, pregnancy of artificially inseminated cats was evaluated 15 days after insemination using an ultrasonic imaging diagnosis system (ALOKA ECHO VISION SSD-500EV) [1]. In pregnant animals, the development of the embryo was observed every five days after the confirmation of pregnancy. The number of kits was counted on the delivery day.

Statistical analysis: The results of this experiment were analyzed by Student's $t$-test and $\chi^{2}$ test.

\section{RESULT}

Quality of frozen semen: The qualities of frozen feline semen diluted with EYT-FC and EYC after thawing are shown in Table 2.

The sperm motility was $80-90 \%$ at semen collection. The 
Table 2. The quality of frozen semin in cats

\begin{tabular}{|c|c|c|c|c|c|c|c|c|c|c|c|c|c|c|}
\hline \multirow{3}{*}{ Extender } & \multirow{3}{*}{$\begin{array}{c}\text { Tom } \\
\text { No. }\end{array}$} & \multirow{3}{*}{$\begin{array}{l}\text { Age } \\
\text { (years) }\end{array}$} & \multicolumn{6}{|c|}{ Initial } & \multicolumn{5}{|c|}{ Post thaw } & \\
\hline & & & \multirow{2}{*}{$\begin{array}{c}\text { Motility } \\
(\%)\end{array}$} & \multirow{2}{*}{$\begin{array}{c}\text { Viability } \\
(\%)\end{array}$} & \multicolumn{4}{|c|}{ Abnormality (\%) } & \multirow{2}{*}{$\begin{array}{c}\text { Motility } \\
(\%)\end{array}$} & \multirow{2}{*}{$\begin{array}{l}\text { Viability } \\
(\%)\end{array}$} & \multicolumn{4}{|c|}{ Abnormality (\%) } \\
\hline & & & & & Head & Mid-piece & Tail & $\overline{\text { Total }}$ & & & Head & Mid-piece & Tail & Total \\
\hline \multirow{6}{*}{ 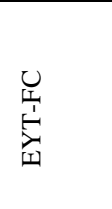 } & $\mathrm{T} 4$ & 12 & 90 & 93.1 & 0 & 0 & 3.0 & 3.0 & 25 & 45.4 & 0 & 3.0 & 21.0 & 24.0 \\
\hline & $\mathrm{T} 32$ & 4 & 90 & 93.8 & 2.0 & 0 & 1.0 & 3.0 & 20 & 45.6 & 2.0 & 2.0 & 23.0 & 27.0 \\
\hline & $\mathrm{T} 40$ & 2 & 90 & 94.9 & 0 & 0 & 1.0 & 1.0 & 55 & 68.4 & 0 & 5.0 & 10.0 & 15.0 \\
\hline & $\mathrm{T} 40$ & 2 & 80 & 78.7 & 4.0 & 2.0 & 2.0 & 8.0 & 20 & 52.9 & 2.0 & 3.0 & 4.0 & 9.0 \\
\hline & Mean & & 87.5 & 90.1 & 1.5 & 0.5 & 1.8 & $3.8^{* * *}$ & 30.0 & 53.1 & 1.0 & 3.3 & 15.0 & 18.8 \\
\hline & $\pm \mathrm{SE}$ & & 2.8 & 4.4 & 1.1 & 0.6 & 0.6 & 1.7 & 9.7 & 6.2 & 0.7 & 0.7 & 5.2 & 4.8 \\
\hline \multirow{6}{*}{$\underset{\nearrow}{\circlearrowright}$} & $\mathrm{T} 4$ & 12 & 80 & 94.0 & 1.0 & 1.0 & 3.0 & 5.0 & 35 & 38.1 & 1.0 & 3.0 & 27.7 & 31.7 \\
\hline & T32 & 4 & 80 & 82.0 & 0.9 & 4.3 & 2.6 & 7.8 & 25 & 57.0 & 2.0 & 0 & 19.0 & 21.0 \\
\hline & T36 & 2 & 85 & 90.8 & 1.0 & 0 & 5.3 & 6.3 & 35 & 48.9 & 0 & 0 & 32.0 & 32.0 \\
\hline & $\mathrm{T} 40$ & 2 & 90 & 93.0 & 0 & 4.0 & 1.0 & 5.0 & 25 & 58.7 & 1.0 & 0 & 30.0 & 31.0 \\
\hline & Mean & & 83.8 & 90.0 & 0.7 & 1.7 & 3.0 & 6.0 & 30.0 & 50.7 & 1.0 & 0.8 & 27.2 & 28.9 \\
\hline & $\pm \mathrm{SE}$ & & 2.8 & 3.2 & 0.3 & 0.8 & 1.0 & 0.8 & 3.3 & 5.4 & 0.5 & 0.9 & 3.3 & 3.1 \\
\hline
\end{tabular}

**: Significantly different from initial abnormality at $\mathrm{p}<0.01$.

Table 3. Conception by UIUI of frozen semen in cats (EYT-FC)

\begin{tabular}{|c|c|c|c|c|c|c|c|c|c|c|c|}
\hline \multirow{3}{*}{$\begin{array}{l}\text { Queen } \\
\text { No. }\end{array}$} & \multirow{3}{*}{$\begin{array}{l}\text { Tom } \\
\text { No. }\end{array}$} & \multirow{3}{*}{$\begin{array}{l}\text { Period of } \\
\text { storage } \\
\text { (month) }\end{array}$} & \multicolumn{4}{|c|}{ Semen quality (\%) } & \multirow{3}{*}{$\begin{array}{l}\text { Interval from } \\
\text { hCG admin. } \\
\text { to AI (hr) }\end{array}$} & \multirow{2}{*}{\multicolumn{2}{|c|}{$\begin{array}{c}\text { No. of mature } \\
\text { follicles }\end{array}$}} & \multirow{3}{*}{$\begin{array}{l}\text { No. of } \\
\text { kits }\end{array}$} & \multirow{3}{*}{$\begin{array}{l}\text { Gestation } \\
\text { period } \\
\text { (day) }\end{array}$} \\
\hline & & & \multicolumn{2}{|c|}{ Initial } & \multicolumn{2}{|c|}{ Post thaw } & & & & & \\
\hline & & & Motility & Viability & Motility & Viability & & $\mathrm{L}$ & $\mathrm{R}$ & & \\
\hline 116 & T36 & 1 & 90 & 92.7 & 20 & 64.1 & $\mathbb{M}$ & 2 & $4 *$ & No ovulation & \\
\hline D6 & $\mathrm{T} 32$ & 1 & 85 & 92.5 & 30 & 51.8 & & 1 & $4 *$ & 2 & 65 \\
\hline 97 & T36 & 1 & 85 & 82.4 & 40 & 65.9 & & $2 *$ & 2 & No ovulation & \\
\hline 113 & $\mathrm{~T} 40$ & 1 & 85 & 91.6 & 30 & 66.1 & 1 & $2 *$ & 1 & Ab. $(48)^{* *}$ & \\
\hline 134 & T32 & 1 & 90 & 92.4 & 30 & 66.2 & 20 & 3 & $6^{*}$ & - & \\
\hline D6-2 & T31 & 9 & 85 & 90.1 & 20 & 43.0 & & $4 *$ & 2 & 4 & 63 \\
\hline $116-2$ & T32 & 10 & 80 & 94.2 & 15 & 65.2 & & 3 & $3^{*}$ & 1 & 68 \\
\hline 128 & T32 & 9 & 85 & 89.3 & 20 & 51.6 & & $3^{*}$ & 3 & - & \\
\hline 122 & $\mathrm{~T} 36$ & 1 & 90 & 92.7 & 30 & 57.2 & V & 2 & $2^{*}$ & - & \\
\hline Mean & & 3.8 & 86.1 & 90.9 & 26.1 & 59.0 & & $2.6 \pm 0.4$ & $3.0 \pm 0.7$ & 2.3 & 65.3 \\
\hline$\pm \mathrm{SE}$ & & 1.5 & 1.2 & 1.2 & 2.8 & 3.0 & & & $5 \pm 0.8$ & 1.1 & 1.8 \\
\hline
\end{tabular}

$*$ : Inseminated side .**: Abortion.

sperm motility and viability of the semen diluted with EYTFC after thawing were $20-50 \%$ (Mean \pm SE: $30.0 \pm 9.7 \%$ ) and $45.4-68.4 \%(53.1 \pm 6.2 \%)$, respectively. The sperm abnormality was $3.8 \pm 1.7 \%$ in the fresh semen, but had increased to $18.8 \pm 4.8 \%$ after thawing. In the EYC group, the sperm motility and viability after thawing were $25-35 \%$ $(30.0 \pm 3.3 \%)$ and $38.1-58.7 \%(50.7 \pm 5.4 \%)$, respectively. The mean sperm abnormality was $6.0 \pm 0.8 \%$ in the fresh semen, but had increased to $28.9 \pm 3.1 \%$ after thawing. The abnormality was clearly increased especially in the tail region by freezing $(\mathrm{P}<0.01)$.

These observation indicate there were no differences in the semen qualities after thawing between the semen prepared with the two extenders.

Conception results of UIUI of frozen feline semen diluted with EYT-FC: The conception results of UIUI of frozen feline semen prepared with EYT-FC are shown in Table 3. $\mathrm{AI}$ was performed $20 \mathrm{hr}$ after hCG administration.

Semen frozen for $1-10$ months after preparation $(3.8 \pm 1.5$ months) was used in AI. The sperm motility and viability after thawing were $15-40 \%(26.1 \pm 2.8 \%)$ and $43.0-66.2 \%$ $(59.0 \pm 3.0 \%)$, respectively. Excluding two cats in which ovulation did not occur, four of seven animals (57.1\%) became pregnant by UIUI. In all of these animals, AI was performed before ovulation. Among the pregnant animals, abortion occurred in No. 113 on day 48 of gestation, but the other three animals delivered $1-4$ kits ( $2.3 \pm 1.1$ kits) on days 63-68 of gestation.

Conception results of UIUI of frozen feline semen diluted with EYC: The results of UIUI of frozen feline semen prepared with EYC are shown in Table 4. AI was performed on four animals at 15 and $20 \mathrm{hr}$ after hCG administration.

The semen frozen for 6-19 months after preparation (8.4 \pm 1.6 months) was used in AI. The sperm motility and viability after thawing were $20-35 \%(28.1 \pm 2.2 \%)$ and $46.6-77.5 \%$ $(61.2 \pm 3.6 \%)$, respectively. Excluding one cat in which ovulation did not occur, four of seven animals $(57.1 \%)$ were fertilized by UIUI. Among the pregnant animals, early embryonic death occurred in No. 137 on day 20 of gestation, but each of the other three cats delivered one kit on days 66- 
Table 4. Conception by UIUI of frozen semen in cats (EYC)

\begin{tabular}{|c|c|c|c|c|c|c|c|c|c|c|c|}
\hline \multirow{3}{*}{$\begin{array}{l}\text { Queen } \\
\text { No. }\end{array}$} & \multirow{3}{*}{$\begin{array}{l}\text { Tom } \\
\text { No. }\end{array}$} & \multirow{3}{*}{$\begin{array}{l}\text { Period of } \\
\text { storage } \\
\text { (month) }\end{array}$} & \multicolumn{4}{|c|}{ Semen quality (\%) } & \multirow{3}{*}{$\begin{array}{l}\text { Interval } \\
\text { from hCG } \\
\text { admin. to AI } \\
\text { (hr) }\end{array}$} & \multirow{2}{*}{\multicolumn{2}{|c|}{$\begin{array}{l}\text { No.of mature follicles } \\
\text { (No. of ovulations) }\end{array}$}} & \multirow{3}{*}{$\begin{array}{c}\text { No. of } \\
\text { kits }\end{array}$} & \multirow{3}{*}{$\begin{array}{c}\text { Gestation } \\
\text { period } \\
\text { (day) }\end{array}$} \\
\hline & & & \multicolumn{2}{|c|}{ Initial } & \multicolumn{2}{|c|}{ Post thaw } & & & & & \\
\hline & & & Motility & Viability & Motility & Viability & & $\mathrm{L}$ & $\mathrm{R}$ & & \\
\hline 131 & $\mathrm{~T} 4$ & 7 & 80 & 88.9 & 30 & 64.3 & $\uparrow$ & $3 *$ & 0 & 1 & 66 \\
\hline $128-2$ & $\mathrm{~T} 32$ & 6 & 90 & 97.0 & 30 & 46.6 & 15 & $3 *$ & 2 & - & \\
\hline D12 & $\mathrm{T} 44$ & 8 & 90 & 93.8 & 35 & 77.5 & 15 & 2 & $3 *$ & 1 & 69 \\
\hline $122-2$ & T36 & 6 & 90 & 94.9 & 25 & 60.0 & $\downarrow$ & $5^{*}$ & 3 & - & \\
\hline $131-2$ & $\mathrm{~T} 44$ & 7 & 90 & 93.8 & 35 & 56.2 & $\uparrow$ & $2 *$ & 1 & No ovulation & \\
\hline 137 & $\mathrm{~T} 32$ & 19 & 90 & 92.7 & 30 & 69.7 & 20 & $4^{*}$ & 1 & $\operatorname{EED}(20)^{* * *}$ & \\
\hline 114 & $\mathrm{~T} 36$ & 7 & 90 & 95.8 & 20 & 59.6 & 20 & $4^{*}$ & 1 & 1 & 67 \\
\hline $97-2$ & $\mathrm{~T} 44$ & 7 & 90 & 92.4 & 20 & 55.3 & $\downarrow$ & (2) & $(3)^{*}$ & - & \\
\hline Mean & & 8.4 & 88.8 & 93.7 & 28.1 & 61.2 & & $33 \pm 0.5$ & $1.9 \pm 0.5$ & 1.0 & 67.3 \\
\hline \pm 32 & & 1.6 & 1.3 & 0.9 & 2.2 & 3.6 & & & 0.6 & 0 & 1.1 \\
\hline
\end{tabular}

*: Inseminated side. **: Early embryonic death.

Table 5. The number of kits compared to the number of ovulations in the inseminated side in unilateral IUI of frozen feline semen

\begin{tabular}{|c|c|c|c|c|c|}
\hline \multirow{2}{*}{ Extender } & \multirow{2}{*}{$\begin{array}{l}\text { Queen } \\
\text { No. }\end{array}$} & \multicolumn{2}{|c|}{ No. of mature follicles } & \multirow{2}{*}{$\begin{array}{l}\text { No. of kits } \\
\text { (a) }\end{array}$} & \multirow{2}{*}{$\begin{array}{c}\text { a/No. of } \\
\text { ovulations (\%) }\end{array}$} \\
\hline & & $\mathrm{L}$ & $\mathrm{R}$ & & \\
\hline \multirow{4}{*}{ EYT-FC } & D6 & 1 & $4 *$ & 2 & $2 / 4(50.0)$ \\
\hline & D6-2 & $4^{*}$ & 2 & $4 * *$ & 4/4 (100) \\
\hline & 116 & 3 & $3 *$ & 1 & $1 / 3(33.3)$ \\
\hline & $\mathrm{M} \pm \mathrm{SE}$ & $2.6 \pm 1.1$ & $3.0 \pm 0.7$ & $2.3 \pm 1.1$ & $61.1 \pm 24.5$ \\
\hline \multirow{4}{*}{ EYC } & 131 & $3 *$ & 0 & 1 & $1 / 3(33.3)$ \\
\hline & D12 & 2 & $3^{*}$ & 1 & $1 / 3(33.3)$ \\
\hline & 114 & $4 *$ & 1 & $1 * *$ & $1 / 4(25.0)$ \\
\hline & $\mathrm{M} \pm \mathrm{SE}$ & $3.0 \pm 0.7$ & $1.3 \pm 1.1$ & $1.0 \pm 0$ & $30.5 \pm 3.4$ \\
\hline
\end{tabular}

*: Inseminated side.

69 of gestation.

Ovulation induction: Ovulation was induced by hCG administration in 14 of 17 animals (ovulation induction rate: $82.4 \%$ ). Excluding three cases in which ovulation did not occur, the ovulation induction rate at each time point after hCG administration was $0 \%(0 / 4)$ after $15 \mathrm{hr}$ and $10.0 \%$ (1/ 10) after $20 \mathrm{hr}$.

The number of kits compared to the number of ovulations in the inseminated side in UIUI of frozen feline semen: The ratio of the number of kits to the number of ovulations in the inseminated side obtained by UIUI of frozen feline semen is shown in Table 5. One case each of abortion and early embryonic death were excluded from the data.

The number of kits (fertility rate) compared to the number of ovulations in the inseminated side was 33.3-100\% (61.1 \pm $24.5 \%$ ) in three pregnant animals in the EYT-FC group. The fertility rate in the three pregnant animals in the EYC group was $25.0 \%$ or $33.3 \%$, and the mean rate was $30.5 \pm 3.4 \%$. Therefore, the fertility rate tended to be higher in the EYTFC group than the EYC group. However, the number of kits did not exceed the number of ovulations in the inseminated side in any of the animals in either group.

Time of UIUI after $h C G$ and conception rate: The relationship between the time of UIUI after hCG and the concep-
Table 6. Time of IUI after hCG and conception rate in cats

\begin{tabular}{cccc}
\hline \multirow{2}{*}{ Extender } & \multicolumn{2}{c}{ Interval from hCG admin. to AI (hr) } & Conception \\
\cline { 2 - 3 } & 15 & 20 & $(\%)$ \\
\hline \multirow{2}{*}{ EYT-FC } & - & $4 / 7$ & $4 / 7$ \\
EYC & $2 / 4$ & $(57.1)$ & $(57.1)$ \\
& $(50.0)$ & $2 / 3$ & $4 / 7$ \\
\multirow{2}{*}{ Total } & $2 / 4$ & $(66.7)$ & $(57.1)$ \\
\hline & $(50.0)$ & $6 / 10$ & $8 / 14$ \\
& & $(60.0)$ & $(57.1)$ \\
\hline
\end{tabular}

tion rate is shown in Table 6.

In the EYT-FC group, AI was performed $20 \mathrm{hr}$ after hCG administration in all cases, and four of seven animals (57.1\%) were fertilized. In the EYC group, the conception rates were $50.0 \%$ (2/4) and $66.7 \%$ (2/3) 15 and $20 \mathrm{hr}$ after hCG administration, respectively, showing, no difference in the conception rate between AI performed at $15 \mathrm{hr}$ and $20 \mathrm{hr}$ after hCG administration.

\section{DISCUSSION}

Because Platz et al. [3] did not clarify the qualities of frozen feline semen after thawing, we could not compare our 
results with their results. There were no differences in the semen qualities after thawing and the conception rate between the two extenders in our study. However, the timecourse changes in the sperm motility after thawing were slightly higher in the semen diluted with EYT-FC than the semen diluted with EYC.

In our previous study of UIUI of fresh semen, the conception rates were $31.3 \%$ and $80.0 \%$ at sperm counts of $4 \times 10^{6}$ and $8 \times 10^{6}$, respectively [7]. In this study, $50 \times 10^{6}$ sperm were used and the motility was $15-40 \%$ (approximately $25 \%$ ). Therefore, the mean number of viable sperms was $12.5 \times 10^{6}$. However, the conception rate $(57.1 \%)$ was lower than that $(80.0 \%)$ obtained by insemination of fresh semen at a sperm count of $8 \times 10^{6}$. Regarding the number of kits compared to the number of ovulations in the inseminated side, ova in the non-inseminated uterine horn were fertilized in approximately half of the fertilized cases by insemination of fresh semen [7]. In contrast, in this study using frozen semen, such cases were not observed, suggesting that although the sperm are motile after thawing, frozen semen is greatly inferior in fertility to fresh semen. Therefore, to increase the fertility and conception rates of IUI of frozen semen, insemination into both uterine horns may be important. It is also considered important to investigate a non-surgical method of artificial insemination.

Because a constant number of sperms, $50 \times 10^{6}$, was inseminated, the sperm count required for fertilization could not be determined in this study. The primary cause of the low conception rate of $57.1 \%$ in this study may have been the small number of sperm inseminated, and it will be necessary to investigate the sperm count required for fertilization by insemination of frozen semen. The duration of storage used in the eight fertilized cases was 1-19 months (Mean: 7-8 months). Since conception was obtained using long-term stored semen in this study, the semen qualities may not be affected by duration of storage. In this study, we used a Cell Freezer to ensure uniform freezing conditions. However, it may be necessary to compare its usefulness with those of other freezing methods.

\section{REFERENCES}

1. Davidson, A.P., Nyland, T.G. and Tsutsui, T. 1986. Pregnancy diagnosis with ultrasound in the domestic cat. Vet. Radiol. 27: 109-114

2. Munro, C. and Stabenfeldt, G.H. 1983. Development of a microtiter plate enzyme immunoassay for the determination of progesterone. J. Endocrinol. 101: 41-49.

3. Platz, C.C., Wildt, D.E. and Seager, S.W.J. 1978. Pregnancy in the domestic cat after artificial insemination with previously frozen spermatozoa. J. Reprod. Fertil. 52: 279-282.

4. Salisbury, G.W., Fuller, H.K. and Willett, E.L. 1941. Preservation of bovine spermatozoa in yolk citrate diluent and field results from its use. J. Dairy Sci. 24: 905-910.

5. Tanaka, A., Kuwabara, S., Takagi, Y., Nakagawa, K., Fujimoto, Y., Murai, M. and Tsutsui, T. 2000. Effect of ejaculation intervals on semen quality in cats. J. Vet. Med. Sci. 62: 1057-1161.

6. Tanaka, A., Takagi, Y., Nakagawa, K., Fujimoto, Y., Hori, T. and Tsutsui, T. 2000. Artificial intravaginal insemination using fresh semen in cats. J. Vet. Med. Sci. 62: 1163-1167.

7. Tsutsui, T., Tanaka, A., Takagi, Y., Nakagawa, K., Fujimoto, Y., Murai, M., Anzai, M. and Hori, T. 2000. Unilateral intrauterine horn insemination of fresh semen in cats. J. Vet. Med. Sci. 62: $1241-1245$. 